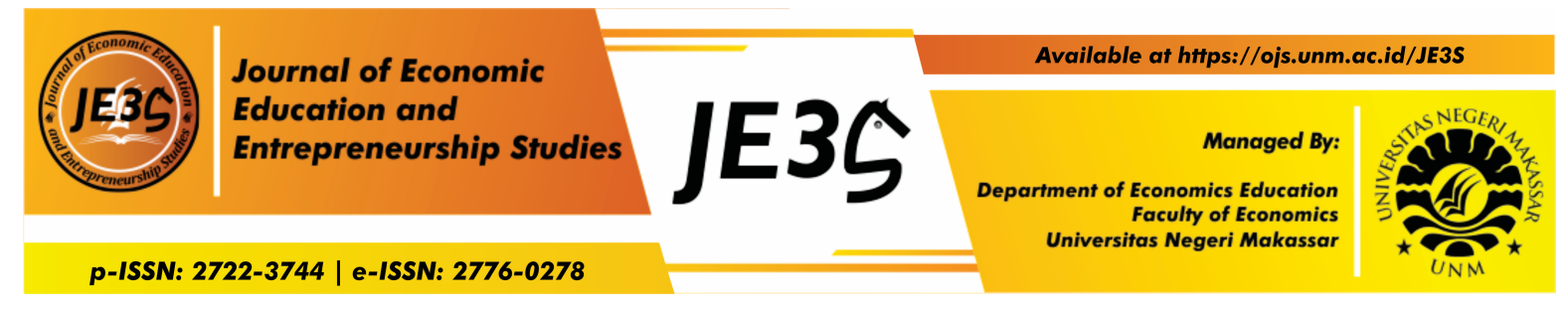

\title{
Pengaruh Media Promosi Internet dan Personal selling terhadap Keputusan Pembelian Produk Skin care Sr Olshop di Kota Makassar
}

Samsinar ${ }^{* 1}$, Salamun Pasda ${ }^{2}$, Muhammad Hasan ${ }^{3}$, M. Ihsan Said Ahmad ${ }^{4}$, Muhammad Dinar ${ }^{5}$ 1,2,3,4,5Fakultas Ekonomi Universitas Negeri Makassar

\section{Article History \\ Received October 11, 2020 \\ Approved November 10, 2020 \\ Published December 30, 2020}

\begin{tabular}{l}
\hline \multicolumn{1}{c}{ Keywords } \\
\hline $\begin{array}{l}\text { Internet Promotion Media, Personal } \\
\text { selling and Purchasing Decisions }\end{array}$ \\
\hline \multicolumn{1}{c}{ JEL Classification } \\
\hline L21, L23, L25, L26 \\
\hline \multicolumn{1}{c}{ How to Cite } \\
\hline Samsinar, Pasda, S., Hasan, M., Ahmad, \\
M. I. S., \& Dinar, M. 2020. Pengaruh \\
Media Promosi Internet dan Personal \\
selling terhadap Keputusan Pembelian \\
Produk Skin care Sr Olshop di Kota \\
Makassar. Journal of Economic \\
Education and Entrepreneurship Studies, \\
1(2), 78-87.
\end{tabular}

\begin{abstract}
This study examines how the influence of internet promotion media and personal selling on the purchasing decisions of SR Olshop skin care products in Makassar City. This research is categorized as a qualitative descriptive study with a population of 49 people who are consumers of SR Olshop skin care products in Makassar City, especially in the Antang area, Kec. Manggala. The data was collected by means of observation, questionnaires and documentation. The analysis technique used is descriptive statistical analysis and inferential statistical analysis. The results showed that the promotional media variable had a positive and significant effect on the purchasing decision of SR Olshop skin care products in Makassar City, while the personal selling variable had a negative and insignificant effect on the purchase of SR Olshop skin care products in Makassar City.
\end{abstract}

\footnotetext{
*Samsinar

Jl. Tamangapa Raya No.160

Makassar, Sulawesi Selatan, Kode Pos 90235

e-mail: samsinar.sidu23@gmail.com
}

(C) 2020 Universitas Negeri Makassar

\section{PENDAHULUAN}

Saat ini konsumen membutuhkan produk skin care sebagai perawatan kulitnya. Skin care merupakan serangkain aktivitas yang mendukung kesehatan kulit dalam meningkatkan penampilan dan meringankan kondisi kulit. Skin care dapat mencakup nutrisi kulit sehingga dapat melindungi dari paparan sinar matahari yang berlebihan.Namun sebelum melakukan perawatan kulit atau menggunakan skin care sebaiknya konsumen mengetahui terlebih dahulu jenis kulit seperti apa yang dimiliki. Sebab apabila konsumen salah menggunakan produk dan tidak sesuai dengan jenis 
kulit maka akan menimbulkan dampak buruk seperti jerawat, kekeringan atau masalah kulit lainnya. Ketika konsumen telah mengetahui jenis kulit yang dimiliki, maka rutinitas perawatan kulit sehari-hari akan membantu menjaga kesehatan kulit secara keseluruhan dan meminimalisir masalah spesifik seperti jerawat dan bintikbintik gelap. Rutinitas perawatan kulit harian dapat dilakukan pada pagi hari dan malam hari.

Dalam membantu mengatasi masalah konsumen terkait produk skin care, SR Olshop ada sebagai pelopor layanan produk skin care yang bisa diakses dengan menggunakan media sosial instagram.Keputusan pembelian konsumen sebagai pengguna produk Skin care SR Olshop merupakan hal yang paling penting. Dimana Kotler (2009) berpendapat bahwa keputusan pembelian dipengaruhi oleh beberapa indikator dari promosi, yakni Media Promosi dan Pemasaran Langsung. Media Promosi merupakan sarana yang digunakan dalam memperkenalkan, mempromosikan dan aktivitas komunikasi, yang ditujukan kepada calon konsumen secara langsung maupun tidak, dan bersifat mengajak (Persuasif) agar tertarik untuk membeli produk yang ditawarkan.

Jenis media promosi terdiri dari media promosi internet (facebook, instagram, twitter, youtube, whatsApp, dan website), media promosi brosur, media promosi poster, media promosi banner, media promosi televisi, dan media promosi merchandise. Artinya perusahaan harus mampu mempromosikan produknya disemua jenis media promosi, akan tetapi perusahaan SR Olshop lebih menggunakan jenis media promosi internet. Nampaknya jenis media promosi tersebut tidak begitu baik. Hal ini dilihat dari ketidaktepatan konsumen mengakses informasi terkait produk yang ditawarkan karena beberapa konsumen masih awam menggunakan sosial media. Fenomena ini sesuai dengan teori yang dikemukakan oleh Kotler (2009) mengenai indikator jenis media promosi yang mempengaruhi keputusan pembelian.

Pemasaran langsung adalah kemampuan membina hubungan baik dengan konsumen secara langsung dengan harapan akan memperoleh respon dan transaksi langsung dari konsumen. Bentuk pemasaran langsung yang umumdilakukan adalah personal selling (penjualan pribadi), telemarketing (pemasaran jarak jauh), direct mail (surat langsung), catalog marketing (pemasaran katalog), direct response (respon langsung), online marketing (pemasaran online), kiosk marketing (pemasaran kios). Artinya orang-orang perusahaan harus memiliki kemampuan berbahasa yang mempu mempengaruhi konsumen serta perusahaan harus bisa menggunakan semua bentuk pemasaran langsung, akan tetapi perusahaan hanya menggunakan pemasaran langsung dengan cara personal selling (penjualan pribadi). Nampaknya bentuk pemasaran langsung ini tidak begitu mengena kekonsumen. Hal ini dilihat dari kurangnya respon konsumen dalam membuka diri untuk mendengar informasi mengenai produk yang ditawarkan. Fenomena ini sesuai dengan teori yang dikemukakan oleh Kotler (2009) mengenai indikator pemasaran langsung yang mempengaruhi keputusan pembelian.

\section{METODE}

Jenis penelitian yang digunakan dalam penelitian ini adalah jenis penelitian survey. Dimana pendekatan yang digunakan adalah pendekatan kuantitatif yang menganalisis data dengan alat statistik dalam bentuk angka. Teknik pengumpulan data yang digunakan ada tiga macam yaitu berupa observasi, angket dan dokumentasi. Teknik analisis yang digunakan adalah analisis statistic deskriptif dan 
analisis statistik inferensial.

Subjek dalam penelitian ini adalah konsumen produk skin care SR Olshop Di Kota Makassar. Variabel bebas (Independen) adalah variabel yang mempengaruhi atau yang menjadi sebab perubahan atau timbulnya variabel terikat (dependen). Dalam penelitian ini yang menjadi variabel bebas adalah media promosi internet (X1) dan personal selling (X2). Variabel terikat (Dependen) adalah variabel yang dipengaruhi atau yang menjadi akibat karena adanya variabel bebas. Dalam penelitian ini yang menjadi variabel terikat adalah keputusan pembelian (Y).

Pada penelitian ini media promosi internet merupakan variabel X1 dimana Indikator media promosi internet terdiri dari: 1) menarik perhatian, 2) menarik minat, 3) menarik hasrat, 4) menarik tindakan, dan 5) memberikan penutup yang baik. Sedangkan Personal selling merupakan variabel X2 di mana Indikator personal selling terdiri dari: 1) kemampuan komunikasi (communication ability), 2) pengetahuan produk (product knowledge), 3) kreativitas (creativity), dan 4) empati (empathy). Pada penelitian ini keputusan pembelian merupakan variable dependen (Y) dimana Indikator keputusan pembelian terdiri dari: 1) Kemantapan pada sebuah produk, 2) Kebiasaan dalam membeli produk, 3) Memberikan rekomendasi kepada orang lain, dan 4) Melakukan pembelian ulang.

Pengukuran Variabel dalam penelitian ini diukur dengan menggunakan skala Likert. Skala Likert adalah suatu skala psikometrik yang umum digunakan dalam angket dan merupakan skala yang paling banyak digunakan dalam riset berupa survey. Responden hanya memberikan persetujuan atau ketidaksetujuannya tergantung terhadap butir soal tersebut. Data yang berhasil dikumpulkan dari kuesioner selanjutnya akan diukur dengan pengukuran data ordinal dengan bobot sampai 5, dengan kategori: 1) Sangat setuju dengan point 5, 2) Setuju dengan point 4, 3) Kurang setuju dengan point 3,4) Tidak setuju dengan point 2, dan 5) Sangat tidak setuju dengan point 1 .

Populasi dalam penelitian ini adalah konsumen SR Olshop di Kota Makassar. Adapun daerah konsumen SR Olshop di Kota Makassar yang dijadikan acuan dalam penelitian ini adalah daerah Antang Kec. Manggala. Sedangkan Pengambilan sampel pada penelitian ini menggunakan teknik boring sampling yakni sampel yang mewakili jumlah populasi. Jadi jumlah sampel yang digunakan pada penelitian ini adalah sebanyak 49 orang.

Penelitian ini menggunakan dua macam data yaitu data primer dengan menggunakan penyebaran kuesioner kepada responden dan data sekunder yang didapatkan dari buku-buku, jurnal, penelitian terdahulu dan internet. Untuk membuktikan kebenaran hipotesis yang telah dikemukakan.

Instrumen penelitian yang digunakan dalam penelitian ini berupa angket atau kuisioner. Penggunaan instrumen penelitian kali ini bertujuan mencari informasi yang lengkap mengeni suatu masalah, fenomena alam maupun sosial. Data yang didapatkan ialah data kuantitatif sehingga setiap jawaban diberi skor, agar menghasilkan data yang akurat peneliti menggunakan skala Likert.

\section{HASIL DAN DISKUSI}

\section{Uji Validitas}

Uji Validitas digunakan untuk kelayakan butir-butir dalam suatu daftar pertanyaan dalam mendefinisikan variabel. Suatu skala pengukur dikatakan valid apabila skala 
yang tersebut digunakan untuk mengukur apa yang seharusnya diukur. Pengujian dalam penelitian ini dilakukan dengan menggunakan SPSS forWindows dengan kriteria dalam pengukuran kuisioner sebagai berikut: Jika rhitung $\geq$ rtabel maka pertanyaan tersebut dinyatakan valid. Jika rhitung< rtabel maka pertanyaan tersebut dinyatakan tidak valid. Uji validitas untuk variabel media promosi internet terdiri dari 10 item pernyataan. Hasil perhitungan korelasi untuk skor tiap butir pernyataan dengan total skor variabel X1 dapat dilihat sebagai berikut:

Tabel 1. Hasil Uji Validitas Item Pernyataan Variabel X1

\begin{tabular}{cllll}
\hline No Item & $\begin{array}{c}\text { Person } \\
\text { Coreltion } \\
(\mathbf{r} \text {-Hitung) }\end{array}$ & Sig & r Tabel & Kriteria \\
\hline Item 1 & 0,606 & 0,000 & 0,281 & Valid \\
Item 2 & 0,676 & 0,000 & 0,281 & Valid \\
Item 3 & 0,706 & 0,000 & 0,281 & Valid \\
Item 4 & 0,832 & 0,000 & 0,281 & Valid \\
Item 5 & 0,672 & 0,000 & 0,281 & Valid \\
Item 6 & 0,822 & 0,000 & 0,281 & Valid \\
Item 7 & 0,752 & 0,000 & 0,281 & Valid \\
Item 8 & 0,842 & 0,000 & 0,281 & Valid \\
Item 9 & 0,823 & 0,000 & 0,281 & Valid \\
Item 10 & 0,731 & 0,000 & 0,281 & Valid \\
\hline
\end{tabular}

Sumber: Hasil Olah Data, 2020

Hasil pengujian validasi item kuesioner menunjukkan bahwa 10 item pertanyaan, semua item dinyatakan valid (korelasi atau $\mathrm{R}$-Hitung lebih besar dari nilai batas minimum atau $\mathrm{R}$-Tabel dari jumlah responden sebanyak 49) sehingga dikatakan dapat digunakan (diterima) untuk mengukur variabel (X1) yang diteliti.

Uji validitas untuk variabel personal selling terdiri dari 10 item pernyataan. Hasil perhitungan korelasi untuk skor tiap butir pernyataan dengan total skor variabel X2 dapat dilihat sebagai berikut:

Tabel 2. Hasil Uji Validitas Item Pernyataan Variabel X2

\begin{tabular}{clllc}
\hline No Item & $\begin{array}{c}\text { Person } \\
\text { Corelation } \\
\text { (r-Hitung) }\end{array}$ & Sig & r- Tabel & Kriteria \\
\hline Item 1 & 0,733 & 0,000 & 0,281 & Valid \\
Item 2 & 0,748 & 0,000 & 0,281 & Valid \\
Item 3 & 0,738 & 0,000 & 0,281 & Valid \\
Item 4 & 0,706 & 0,000 & 0,281 & Valid \\
Item 5 & 0,648 & 0,000 & 0,281 & Valid \\
Item 6 & 0,624 & 0,000 & 0,281 & Valid \\
Item 7 & 0,820 & 0,000 & 0,281 & Valid \\
Item 8 & 0,663 & 0,000 & 0,281 & Valid
\end{tabular}




$\begin{array}{ccccc}\text { Item } 9 & 0,815 & 0,000 & 0,281 & \text { Valid } \\ \text { Item } 10 & 0,728 & 0,000 & 0,281 & \text { Valid }\end{array}$

Sumber: Hasil Olah Data, 2020

Hasil pengujian validasi item kuesioner menunjukkan bahwa 10 item pertanyaan, semua item dinyatakan valid (korelasi atau R-Hitung lebih besardari nilai batas minimum atau $\mathrm{R}$-Tabel dari jumlah responden sebanyak 49) sehingga dikatakan dapat digunakan (diterima) untuk mengukur variabel (X2) yang diteliti. Uji validitas untuk variabel keputusan pembelian terdiri dari 10 item pernyataan. Hasil perhitungan korelasi untuk skor tiap butir pernyataan dengan total skor variabel X2 dapat dilihat sebagai berikut:

Tabel 3. Hasil Uji Validitas Item Pernyataan Variabel Y

\begin{tabular}{cllll}
\hline No Item & $\begin{array}{c}\text { Person } \\
\text { Coreltion } \\
\text { (r-Hitung) }\end{array}$ & Sig & r- Tabel & Kriteria \\
\hline Item 1 & 0,802 & 0,000 & 0,281 & Valid \\
Item 2 & 0,794 & 0,000 & 0,281 & Valid \\
Item 3 & 0,730 & 0,000 & 0,281 & Valid \\
Item 4 & 0,847 & 0,000 & 0,281 & Valid \\
Item 5 & 0,772 & 0,000 & 0,281 & Valid \\
Item 6 & 0,872 & 0,000 & 0,281 & Valid \\
Item 7 & 0,972 & 0,000 & 0,281 & Valid \\
Item 8 & 0,662 & 0,000 & 0,281 & Valid \\
Item 9 & 0,823 & 0,000 & 0,281 & Valid \\
Item 10 & 0,884 & 0,000 & 0,281 & Valid \\
\hline
\end{tabular}

Sumber: Hasil Olah Data, 2020

Hasil pengujian validasi item kuesioner menunjukkan bahwa 10 item pertanyaan, semua item dinyatakan valid (korelasi atau $\mathrm{R}$-Hitung lebih besar dari nilai batas minimum atau $\mathrm{R}$-Tabel dari jumlah responden sebanyak 49) sehingga dikatakan dapat digunakan (diterima) untuk mengukur variabel (Y) yang diteliti.

\section{Uji Reliabilitas}

Pengujian reliabilitas dengan bantuan SPSS for windows Realeas menggunakan metode Cronbach's Alpha maka $\mathrm{r}$ hitung diwakili oleh nilai alpha. Jika nilai Cronbach's Alpha > 0,60 maka kuesioner yang diuji coba terbukti reliabel. Uji reliabiltas ini digunakan untuk menguji apakah suatu instrumen sudah reliabel atau dapat menghasilkan data yang dipercaya. Instrumen yang reliabel adalah walaupun berkali-kali diambil hasilnya tetap sama, jadi reliabilitas adalah sejauh mana hasil pengukuran terjadi apabila pengukuran dilakukan pada kelompok subjek yang sama. Berikut ini adalah table hasil uji reliabilitas item - item pernyataan dari ketiga variabel dalam penelitian ini. 
Tabel 4. Hasil Uji Reliabelitas

\begin{tabular}{clccl}
\hline No & \multicolumn{1}{c}{ Variabel } & $\begin{array}{c}\text { Cronbach } \\
\text { Alpha }\end{array}$ & r-Tabel & Kriteria \\
\hline 1 & Media Promosi Internet & 0,911 & 0,600 & Reliabel \\
2 & Personal Selling & 0,898 & 0,600 & Reliabel \\
3 & Keputusan Pembelian & 0,936 & 0,600 & Reliabel \\
\hline
\end{tabular}

Sumber: Hasil Olah Data, 2020

\section{Uji Asumsi Klasik}

Uji normalitas adalah pengujian tentang kenormalan distribusi data sehingga dapat dipakai dalam statistic parametric (statistic inferensial). Uji normalitas bertujuan untuk mengetahui apakah masing-masing variabel berdistribusi normal atau tidak. Uji normalitas diperlukan karena untuk melakukan pengujian- pengujian variabel lainnya dengan mengansumsikan bahwa nilai residual mengikuti distribusi normal.

Tabel 5. Hasil Uji Normalitas Data One-Sample Komogrof-Sminov Test

\begin{tabular}{lccc}
\hline Variabel & Asymp. Sig & $\begin{array}{c}\text { Taraf } \\
\text { Signifikansi }\end{array}$ & Ket \\
\hline Media Promosi Internet & 0,200 & 0,5 & Normal \\
Personal Selling & 0,200 & 0,5 & Normal \\
Keputusan Pembelian & 0,200 & 0,5 & Normal \\
\hline
\end{tabular}

Sumber: Hasil Olah Data, 2020

Berdasarkan Tabel 5 hasil pengujian One-Sample Kolmogorov-Smirnov Test menghasilkan asymptotic significance sebesar $0,200 \geq 0,05$. Berdasarkan hasil tersebut maka dapat disimpulkan bahwa model regresi telah memenuhi asumsi kenormalan.

Uji linearitas bertujuan untuk melihat apakah spesifikasi model yang digunakan sudah benar atau tidak. Suatu data dikatakan linier apabila nilai signifikan deviation from linearity lebih besar dari taraf signifikan 0,05. Penelitian ini menggunakan perhitungan program SPSS 21 for windows, hasil uji linearitas tersebut dapat dilihat pada tabel berikut:

Tabel 6. Hasil Uji Linearitas

\begin{tabular}{clccc}
\hline No & \multicolumn{1}{c}{ Variabel } & $\begin{array}{c}\text { Signifikan } \\
\text { Deviation from } \\
\text { Linearity }\end{array}$ & $\begin{array}{c}\text { Taraf } \\
\text { Signifikansi }\end{array}$ & Keterangan \\
\hline \multirow{2}{1}{$\begin{array}{l}\text { Media Promosi } \\
\text { Internet terhadap } \\
\text { Keputusan Pembelian }\end{array}$} & 0,353 & 0,05 & Linear \\
$\begin{array}{l}\text { Personal selling } \\
\text { terhadap Keputusan } \\
\text { Pembelian }\end{array}$ & 0,024 & 0,05 & Linear \\
\hline
\end{tabular}

Sumber: Hasil Olah Data, 2020 
Berdasarkan tabel menunjukkan bahwa dari pengolahan data menggunakan SPSS 21 for windows didapat nilai signifikan deviation from linearity untuk variabel media promosi internet terhadap keputusan pembelian sebesar 0,533, nilai signifikan deviation from linearity untuk variabel personal selling terhadap keputusan pembelian sebesar 0,024. Berdasarkan penjelasan tersebut dapat disimpulkan bahwa media promosi internet dan keputusan pembelian adalah linear, sehingga dapat diartikan bahwa hubungan antara Media Promosi Internet (X1) terhadap Keputusan Pembelian (Y) mempunyai arah yang positif. Sedangkan personal selling dan keputusan pembelian adalah tidak linear, sehingga dapat diartikan bahwa hubungan antara Personal selling (X2) terhadap Keputusan Pembelian (Y) mempunyai arah yang negatif.

\section{Uji Regresi Linier Berganda}

Pengujian menggunakan analisis regresi berganda yang bertujuan untuk mengetahui pengaruh variabel media promosi internet (X1) dan personal selling (X2) terhadap keputusan pembelian (Y) produk skin care SR Olshop di Kota Makassar. Berdasarkan perhitungan SPPS 21 for windows dapat dilihat sebagai berikut:

Tabel 7. Hasil Uji Analisis Regresi Linear Berganda. Coefficients $^{\mathrm{a}}$

\begin{tabular}{|c|c|c|c|c|c|}
\hline \multirow[t]{2}{*}{ Model } & & $\begin{array}{l}\text { Ustandardized } \\
\text { Coefficients }\end{array}$ & \multirow{2}{*}{$\begin{array}{c}\begin{array}{c}\text { Standardized } \\
\text { Coefficients }\end{array} \\
\text { Beta } \\
\end{array}$} & \multirow[t]{2}{*}{$\mathbf{T}$} & \multirow[t]{2}{*}{ Sig } \\
\hline & & $\begin{array}{ll}\text { B } & \text { Std.Error }\end{array}$ & & & \\
\hline (Constant) & ,802 & 4,012 & & 200 & .376 \\
\hline $\begin{array}{l}\text { Media Promosi } \\
\text { Internet }\end{array}$ &, 742 &, 122 & ,702 & 6,091 & ,000 \\
\hline Personal Selling &, 215 &, 132 & , 189 & 1,636 & 109 \\
\hline
\end{tabular}

Dependent Variable: Keputusan Pembelian

Sumber: Hasil Olah Data, 2020

Berdasarkan Tabel 7 maka diperoleh nilai a (konstan) sebesar 0,802, koefisien $\mathrm{X} 1$ sebesar 0,742 dan X2 sebesar 0,215 sehingga apabila dimasukkan kedalam persamaan regresi diperoleh persamaan sebagai berikut:

$$
\mathrm{Y}=0,802+0,742 \mathrm{X} 1+0,215 \mathrm{X} 2
$$

Berdasarkan persamaan di atas dapat dijelaskan sebagai berikut: Persamaan regresi di atas dapat dijelaskan bahwa nilai konstanta sebesar 0.802 dapat diartikan apabila variabel media promosi internet dan personal selling dianggap konstan atau tidak mengalami perubahan, maka keputusan pembelian sebesar 0.802. Nilai koefisien beta pada media promosi internet sebesar 0,742, bernilai positif menunjukkan bahwa adanya hubungan positif antara variabel media promosi internet terhadap keputusan pembelian. Nilai koefisien regresi sebesar 0,742 mengandung arti bahwa setiap penambahan nilai sebesar satu satuan maka dapat menambah pengaruh keputusan pembelian sebesar 0,742 , nilai koefisien beta pada variabel personal selling sebesar 0,215, yang bernilai positif menunjukkan bahwa adanya hubungan positif antara variabel personal selling terhadap keputusan pembelian. Nilai koefisien regresi sebesar 0,215 mengandung arti bahwa setiap penambahan nilai sebesar satu satuan pada variabel personal selling maka dapat menambah pengaruh keputusan pembelian sebesar 0,215 . 
Untuk mengetahui variabel yang berpengaruh signifikan atau tidak secara parsial dilakukan pengujian koefisien regresi dengan menggunakan statistik nilai T. penentuan hasil pengujian dapat dilakukan dengan membandingkan t-hitung dengan t-tabel atau dapat juga dilihat dari nilai signifikannya. Hasil pengujian hipotesis secara parsial dengan menggunakan SPSS 21 for windows dapat dilihat pada tabel berikut:

Tabel 8. Hasil Uji Signifikan secara Parsial (Nilai t)

\begin{tabular}{|c|c|c|c|c|c|}
\hline \multirow[t]{2}{*}{ Model } & \multicolumn{2}{|c|}{$\begin{array}{l}\text { Ustandardized } \\
\text { Coefficients }\end{array}$} & \multirow{2}{*}{$\begin{array}{r}\begin{array}{r}\text { Standardized } \\
\text { Coefficients }\end{array} \\
\text { Beta }\end{array}$} & \multirow[t]{2}{*}{$\mathbf{t}$} & \multirow[t]{2}{*}{ Sig } \\
\hline & B & Std.Error & & & \\
\hline (Constant) & ,802 & 4,012 & & & ,200 \\
\hline $\begin{array}{l}\text { Media Promosi } \\
\text { Internet }\end{array}$ & ,742 & ,122 & ,702 & 6,091 &, 000 \\
\hline Personal Selling &, 215 & ,132 & 189 & 1,636 & ,109 \\
\hline
\end{tabular}

Sumber: Hasil Olah Data, 2020

Berdasarkan hasil uji signifikansi secara parsial pada tabel nilai signifikansi bertujuan untuk mengetahui apakah variabel independen secara individual mempengaruhi variabel dependen. Berikut Penjelasan pengambilan keputusan antara lain:

a. Variabel media promosi internet (X1) menunjukkan nilai signifikansi sebesar $0,000<0,05$ hasil tersebut menjelaskan bahwa variabel media promosi internet secara individual berpengaruh signifikan terhadap keputusan pembelian produk skin care SR Olshop di Kota Makassar.

b. Variabel personal selling (X2) menunjukkan nilai signifikansi sebesar $0,109<$ 0,05 dari hasil tersebut menjelaskan bahwa variabel personal selling tidak memiliki pengaruh signifikan secara parsial terhadap keputusan pembelian produk skin care SR Olshop di Kota Makassar.

Untuk mengetahui variabel-variabel bebas berpengaruh secara signifikan atau tidak secara simultan terhadap variabel terikat digunakan nilai F. Hasil pengujian hipotesis secara simultan dengan menggunakan SPSS 21 for windows dapat dlihat pada tabel berikut:

Tabel 9. Hasil Uji Signifikan secara Simultan (Uji F)

\begin{tabular}{clcc}
\hline Model & \multicolumn{1}{c}{ Variabel } & Signifikan & $\begin{array}{c}\text { F } \\
\text { Hitung }\end{array}$ \\
\hline Regresion & $\begin{array}{l}\text { Media Promosi Internet } \\
\text { Personal Selling } \\
\text { Keputusan Pembelian }\end{array}$ & 0,000 & 60,996 \\
\hline
\end{tabular}

Sumber: Hasil Olah Data, 2020

Berdasarkan tabel menunjukkan nilai signifikansi 0,000 dan nilai F-hitung sebesar 60,996. Untuk membuat kesimpulan menerima atau menolak Ho, terlebih dahulu ditentukan nilai F-tabel yang digunakan. Dengan menggunakan tingkat signifikan 5\% dan nilai df sebesar $\mathrm{n}-\mathrm{k}$ maka $\mathrm{F}$-tabel $=\mathrm{F}(\mathrm{k}, \mathrm{n}-\mathrm{k})$, dari hasil tersebut diperoleh nilai F-tabel sebesar 3,20. Maka dari itu dapat diketahui nilai sig sebesar $0,000<0,05$ dan nilai F-hitung sebesar 60,996> F-tabel 3,20 dari perhitungan tersebut 
maka Ho ditolak. Dengan demikian dapat disimpulkan bahwa secara simultan variabel independen (media promosi internet dan personal selling) memiliki pengaruh yang signifikan terhadap variabel dependen (keputusan pembelian).

Identifikasi determinasi (R2) berfungsi untuk mengetahui signifikansi variabel maka harus dicari koefisien determinasi (R2). Koefisien determinan menunjukkan besarnya kontribusi variabel independen terhadap variabel dependen. Semakin besar nilai koefisien determinasi, maka semakin baik kemampuan variabel independen menerangkan variabel dependen. Jika determinasi (R2) semakin besar (mendekati satu), maka dapat dikatakan bahwa pengaruh variabel independen adalah besar terhadap variabel dependen. Hal ini berarti, model yang digunakan semakin kuat untuk menerangkan pengaruh variabel independen yang diteliti terhadap variabel dependen.

Tabel 10. Hasil Uji Koefisien Determinasi Model Summary

\begin{tabular}{ccccc}
\hline Model & R & R Square & Adjusted R Square & $\begin{array}{c}\text { Std.Error of the } \\
\text { Estimate }\end{array}$ \\
\hline 1 &, $852 \mathrm{a}$ &, 726 &, 714 & 2,568 \\
\hline
\end{tabular}

a. Predictors: (Constant), Personal Selling, Media Promosi Internet

Sumber: Hasil Olah Data, 2020

Berdasarkan Tabel 10 maka diperoleh nilai korelasi (R) variabel media promosi internet dan personal selling sebesar 0,852. Hal ini menunjukkan bahwa hubungan media promosi internet dan personal selling secara bersama-sama berpengaruh terhadap keputusan pembelian sebesar 0,852 atau sebesar 85,2 persen artinya sangat kuat. Sedangkan nilai koefisien determinasi (R Square) sebesar 0,714 artinya bahwa pengaruh variabel media promosi internet dan personal selling secara bersama-sama berpengaruh terhadap keputusan pembelian sebesar 0,714 atau sebesar 71,4 persen artinya besar dan selebihnya dipengaruhi oleh faktor lain sebesar 28,6 persen.

\section{KESIMPULAN DAN SARAN}

Berdasarkan hasil penelitian dan analisis data yang telah dilakukan, dapat ditarik kesimpulan sebagai berikut:

1. Secara parsial variabel media promosi internet berpengaruh secara positif dan signifikan terhadap keputusan pembelian produk skin care SR Olshop di Kota Makassar.

2. Secara parsial variabel personal selling berpengaruh secara negatif dan tidak signifikan terhadap keputusan pembelian produk skin care SR Olshop di Kota Makassar

\section{DAFTAR PUSTAKA}

Aliyah, Khorik Atul. 2017. Pengaruh Promosi melalui Media Sosial terhadap Keputusan Pembelian dengan Viral Marketing sebagai Variabel Intervensi (Case Study terhadap Konsumen SFA Steak \& Resto Karanganyar). Esai. Institut Agama Islam Negeri Surakarta. 
Anis, Prasetiowati. 2013. Analisis Efek Iklan, Promosi Penjualan, Hubungan Masyarakat, Penjualan Pribadi, dan Pemasaran Langsung Atas Keputusan Pembelian Motor Honda Matik di Surakarta. Esai. Universitas Muhammadiyah Surakarta.

Anoraga, Pandji. 2004. Manajemen Bisnis, Edisi Ketiga. Jakarta: Rineka Cipta.

Hasan, Muhammad. 2018. Pendidikan Ekonomi Informal: Bagaimana Pendidikan Ekonomi Membentuk Pengetahuan dalam Bisnis Keluarga? Jurnal Ekonomi dan Pendidikan JEKPEND, 1 (2), 30 - 37.

Kotler, Philip and Gary Armstrong. 2012. "Prinsip - prinsip Pemasaran. Edisi13. Jilid 1”. Erlangga: Jakarta

Kotler, Philip \& Kevin Lane Keller. 2009, Manajemen Pemasaran. Edisi 13. Jilid 2. Jakarta

Kotler, Philip. 2000. Marketing Management. Edisi Milenium, Prentice Hall Intl, Inc New Jersey.

Nitisusastro, Mulyadi. 2013. Perilaku Konsumen dalam Perspektif Kewirausahaan. Cetakan kedua. Bandung : Alfabeta.

Rangkuti, Freddy. 2009. Strategi Promosi yang Kreatif. Jakarta : PT Gramedia Pustaka Umum.

Schiffman, G. Leon. and Kanuk, L. Leslie. (2007). Perilaku Konsumen. Edisi 7. Terjemahan. Jakarta: Penerbit Indeks. 